\title{
Cocaine and social transformation in Trinidad and Tobago
}

\section{Letter from Trinidad}

\author{
Hari Maharajh
}

The social effects of the introduction of a new drug into any society evades immediate recognition. This may be due to pervasive vells of secrecy because of its illegality, connection with organised crime, concealment by politicians, or an unwillingness of an insensitive population to recognise and accept its presence.

Approximately 15 years ago, cocaine was introduced to Trinidad and Tobago. The Republic's strategic geographical location off the mainland of South America enabled it to become an immediate transhipment port to the United States and Europe. Almost overnight, the legal and penal systems were put to the test as assassinations and homicides rose. Crime and violence increased as the cocaine trade flourished and established itself in society. It trickled into the school system, police force, civil service, and private sector.

On the streets, youths previously impoverished, donned expensive costumes, bearing beepers and mobile phones. They drove around in a menacing manner in rented vehicles sometimes brandishing the most modern uzis and automatic rifles at the slightest provocation. Overnight, many became rich, others became vagrants adding to the increasing number of street dwellers in their search for the third scourge of mankind, cocaine. A new generation of street children previously unknown in the land was born. Shootouts, gang warfares, death by assassination resulted in the now common occurrence of mangled bodies, headless corpses and disembowelled humans on dumps, ravine, swamps and beaches.

The population in alarm became tense. They began to manifest defensive aggression by arming themselves, protecting their homes with cameras, security alarms and killer guard dogs. Architectural home designs changed, becoming more fortress-like. Before their very eyes, they witnessed the erosion of family values as social systems collapsed. They doubted the ability of the law to protect them.

Individuals saw loved ones of friends and families getting involved in drug-related criminal activities, often predicting their demise while accepting the inability of the medical or legal institutions to help them. Involvement in drugs meant death and no place was safe; trust dwindled as the nation's insecurity grew. The law to many was now only a word and money laundering, a thriving business. In addition, the 'passing out' of foreign traffickers was heralded in international headlines that damned the good name of the people's easy going nature. The rum and calypso society was now dead and the twin tropical paradise dubbed an 'at risk' tourist attraction.

The establishment of the cocaine trade has also resulted in a new literary culture. This transformation of the language has changed it from a medium of comprehensive expressions to one studded with new forms of dialect, various inventions of slang and street neologisms. These verbal influences have filtered into everyday usage, hardly decipherable by someone unexposed to the culture.

It is difficult to escape this new-found vernacular which I attempt to capture in one of my poems entitled 'cocaine paranoia'.

Two voices ponging meh head

Oh Godl is better ah dead.

On black and crack, a zooch spranger.

Tull now, I denied de danger.

Two voices jumbie-ing meh system

Fighting-up meh brains for mental decision,

Using cocaine in nightmare and dream

"Ah clean man", ah wake up and scream.

Two voices like a cricket game,

Running commentary dat ah man insane. 
Seeing t'ings in all shapes and sizes On radio and TV, dey plotting disguises.

Two voices laughing at me,

Peeping and searching on meh knee.

Through keyholes and creases on the wall,

Is de police and dem with deh gun and all.

Two voices controlling meh movement. Sprang-a-lang without a black cent, Meh mother jewel pusher, for a ten rock. I used to cut for de boss on the block.

Two voices arguing, ah cyar duss de beat, Is de white lady dat have he so on the street,
It look like dis man really gone through, Better take him to the hospital for a review.

About 100 years ago, Freud was criticised for introducing the third scourge to mankind. The critics seem to have had immense foresight. Today, cocaine has transformed society affecting all social systems. It will be useful for others in distant parts to recognise this transformation while attending to those from here who are in need of help.

Hari D. Maharajh, Consultant Psychiatrist, St. Ann's Hospital, St. Ann's, Trinidad, West Indies

\section{College Seminars Series}

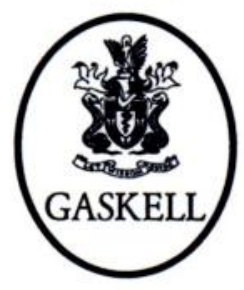

\section{Seminars in Alcohol and Drug Misuse}

\section{Edited by Jonathan Chick and Roch Cantwell}

Psychiatric complications of alcohol and drug misuse must be recognised and treated confidently. This book provides information to meet the needs of practising psychiatrists and will be useful to physicians, psychologists and social workers. A clear review of the aetiology, epidemiology, treatment and prevention of dependence on and misuse of alcohol and illicit and prescribed drugs is presented. With a balance of theory, recent research and practical clinical guidelines, the book covers specific and common problems in mental health as well as in general medicine. El 3.50, 1994, 256pp. ISBN 0902441702

Available from good bookshops and from the Publications Department, Royal College of Psychiatrists, 17 Belgrave Square, London SWIX 8PG. Credit card orders can taken over the telephone $(+44(0) 171-2352351$, extension 146). 